\title{
Serological and virological surveillance of avian influenza virus in domestic ducks of the north-east region of Bangladesh
}

\author{
Rahul Deb Sarker ${ }^{1}$, Mohammad Giasuddin², Emdadul Haque Chowdhury ${ }^{1}$ and Mohammad Rafiqul Islam ${ }^{1 *}$ (D)
}

\begin{abstract}
Background: Wild waterfowl are considered as the natural reservoir for avian influenza (Al) viruses. Bangladesh has been experiencing highly pathogenic avian influenza (HPAl) outbreaks since 2007, mostly in chickens and occasionally in ducks. Ducks play an important role in the persistence and genetic recombination of Al viruses. This paper presents the results of serological and virological monitoring of Al in domestic ducks in 2013 in the north-east region of Bangladesh.

Results: A total of 871 and 662 serum samples and 909 and 302 pairs of cloacal and oropharyngeal swabs from domestic ducks of Mymensingh and Sylhet division, respectively, were analysed. Antibodies to type A influenza virus were detected by blocking ELISA in 60.73 and 47.73\% serum samples of Mymensingh and Sylhet division, respectively. On haemagglutination-inhibition (HI) test 17.5\% of ELISA positive serum samples were found to be seropositive to $\mathrm{H} 5$ avian influenza virus. Five cloacal swabs and one oropharyngeal swab were positive for M gene of type A influenza virus by real time RT-PCR (rRT-PCR), but all of them were negative for H5 influenza virus. Three of the six viruses were successfully characterized as H1N5, H2N5 and H7N5 subtype of Al virus, the other three remained uncharacterized. On sequencing and phylogenetic analysis the HA and NA genes were found to be of Eurasian avian lineage. The $\mathrm{H} 7$ virus had cleavage site motif of low pathogenic virus.
\end{abstract}

Conclusions: Low pathogenic avian influenza viruses were detected from apparently healthy domestic ducks. A small proportion of domestic ducks were found seropositive to $\mathrm{H} 5 \mathrm{Al}$ virus.

Keywords: Avian influenza virus, Ducks, Seroprevalence, Molecular characterization, Phylogenetic analysis

\section{Background}

Wild waterfowl serve as the natural reservoir for Type A influenza viruses and play an important role in the persistence and transmission of these viruses among birds and other mammalian species. Influenza A viruses are classified into subtypes based on two surface proteins, the hemagglutinin (HA) and neuraminidase (NA). At least 16 hemagglutinins ( $\mathrm{H} 1$ to $\mathrm{H} 16)$ and 9 neuraminidases (N1 to N9) have been found in AI viruses from birds [1], while two additional HA and NA types have been identified only in bats [2]. Influenza viruses in birds are classified as either low pathogenic avian influenza (LPAI) or highly pathogenic avian influenza (HPAI)

\footnotetext{
*Correspondence: mrislam_bau@yahoo.com

'Department of Pathology, Bangladesh Agricultural University, Mymensingh, Bangladesh

Full list of author information is available at the end of the article
}

viruses. The HPAI viruses that produce acute clinical disease in chickens, turkeys and other birds belong to either H5 and H7 subtypes. Many different subtypes of AI viruses resulting from the combination of the $16 \mathrm{HA}$ and 9 NA antigens have been found in wild waterfowl [3]. Low pathogenic AI viruses of $\mathrm{H} 5$ or $\mathrm{H} 7$ subtypes also may persist in wild ducks, which may evolve into HPAI viruses. The ancestor of the currently circulating H5N1 HPAI viruses was first detected in bar-headed goose in Guangdong province, China in 1996. Following some genetic recombinations, the global dissemination of this $\mathrm{H} 5 \mathrm{~N} 1$ virus began in 2003 with devastating consequences for the poultry industry [4]. In Bangladesh H5N1 HPAI virus was first detected in $2007[5,6]$ and 550 outbreaks have been reported to OIE until now [7]. Most of the outbreaks were in chickens, but clinical disease also has been observed in quails, crows, ducks 
and geese [8-10]. Three different genetic clades of HPAI H5N1 virus, namely clade 2.2, 2.3.4 and 2.3.2.1 were detected $[8,11,12]$. As of 19 July 2016, 8 human cases of $\mathrm{H} 5 \mathrm{~N} 1 \mathrm{AI}$ virus with one case fatality have been reported from Bangladesh [13]. In addition to H5N1 HPAI, low pathogenic H9N2 influenza virus also has been circulating in poultry [14-16].

Total population of domestic ducks (Anas platyrhynchos) in Bangladesh is 48.86 million [17]. Ducks are reared either in scavenging or semi-intensive system. In scavenging system chickens and ducks are usually reared in the same household. In semi-intensive system ducks are brought to the rivers and lakes for feeding, where they get a chance to mingle with the wild waterfowl. Thus AI viruses can transmit from wild waterfowl to domestic ducks. The present paper reports on the serosurveillance and molecular detection and characterization of AI viruses from domestic ducks in north-eastern districts of Bangladesh.

\section{Methods \\ Sample collection}

An AI surveillance programme was conducted by the Department of Livestock Services (DLS), Bangladesh in collaboration with several national laboratories with assistance from the Food and Agriculture Organisation (FAO) of the United Nations in 2013. The samples we used in this study were collected through this surveillance platform. This surveillance program targeted ducks and swine population of the country. Samples collected by DLS veterinarians from different regions of the country were sent to the nearby national laboratories. Our laboratory was entrusted with the responsibility of analyzing samples from the north-western region of Bangladesh including Mymensingh division (Jamalpur, Sherpur, Tangail, Mymensingh, Netrokona and Kishoreganj districs) and Sylhet division (Sunamganj, Hobiganj, Sylhet and Moulvibazar districts) (Fig. 1). Duck rearing is popular in this region because of the presence of many natural waterbodies. With the exception of Netrokona district there was no clinical outbreak of AI in ducks during the period from 2007 to 2013. Serum samples and cloacal and oropharyngeal swabs of 909 and 671 domestic scavenging or semi-scavenging ducks of more than 8 weeks of age from the Mymensingh and Sylhet division, respectively, were collected during the period from January to August 2013. Cloacal and oropharyngeal swabs were placed individually in cryovials containing virus transport medium. The transport medium was prepared with Dulbecco's modified Eagle Medium supplemented with HEPES (20 mM), L-glutamine (2 mM), gentamycin $(250 \mu \mathrm{g} / \mathrm{ml})$, sulfamethoxazole $(200 \mu \mathrm{g} / \mathrm{ml})$, ofloxacin $(60 \mu \mathrm{g} / \mathrm{ml})$, polymyxin B $(2000 \mathrm{IU} / \mathrm{ml})$, amphotericin B $(2 \mu \mathrm{g} / \mathrm{ml})$ and bovine serum albumin $(2.5 \%)$.
The samples were shipped to the laboratory either in a cooler with ice pack or in liquid nitrogen, depending on the time required for transportation. Blood samples were also collected from the wing vein of the ducks. The blood was allowed to clot and the serum was separated by centrifugation using a portable centrifuge, and shipped to the laboratory maintening the cool chain as mentioned above.

\section{Detection of antibodies to influenza virus}

A blocking ELISA kit (IDEXX AI Multi S-Screen ELISA kit, IDEXX Laboratories, USA) was used to measure antibodies to Type A influenza virus in all the duck serum samples according to manufacturer's instruction. Positive and negative control samples provided with the test kit were included on each plate. Serum samples with a sample-to-negative control $(\mathrm{S} / \mathrm{N})$ absorbance ratio less than 0.50 were considered positive.

A total of 80 serum samples out of 845 ELISA-positive samples were randomly selected. The selected samples had a wide range of ELISA values; $\mathrm{S} / \mathrm{N}$ absorbance ratio 0.10-0.19 ( $n=27), 0.20-0.29(n=16), \quad 0.30-0.39$ $(n=24)$ and $0.40-0.49(n=13)$. These samples were tested for antibodies to $\mathrm{H} 5$ avian influenza virus by haemagglutination-inhibition (HI) test. The $\mathrm{H} 5$ antigen (inactivated allantoic fluid containing $\mathrm{H} 5 \mathrm{~N} 1$ avian influenza virus of clade 2.3.2.1a virus) was obtained from the National Reference Laboratory for Avian Influenza, Bangladesh Livestock Research Institute, Savar, Dhaka. The HI test was performed as described in OIE manual [18].

\section{Molecular detection of avian influenza virus}

Viral RNA was extracted from swab samples with KingFisher ML automated RNA extraction machine (Thermo Scientific, USA) using Ambion MagMAX Viral RNA Isolation Kit (Life Technologies, USA). Extraction protocol provided by the kit manufacturer was adapted to KingFisher ML automated RNA extraction machine.

All samples were first screened for the presence of Type A influenza virus by Taqman real time RT-PCR for $M$ gene [19]. The real time RT-PCR was performed on AB 7500 Fast Real Time PCR machine (Applied Biosystems Inc., USA). The reaction was performed in MicroAmp Optical 96 Well Fast PCR plates using AgPath-ID ${ }^{\mathrm{Tm}}$ One Step RT-PCR kit (Life Technologies, USA) following manufacturer's instruction. The primer and probe sequences are given in Table 1.

All $M$ gene positive samples were then tested for $\mathrm{H} 5$ avian influenza virus by conventional RT-PCR for H5 gene [20]. The one step RT-PCR was performed on Eppendorf Mastercycler Gradient thermocycler (Eppendorf, Germany) using SuperScript ${ }^{\oplus}$ III One-Step RT-PCR System with Platinum $^{\circledR}$ Taq DNA polymerase (life Technologies, USA) 


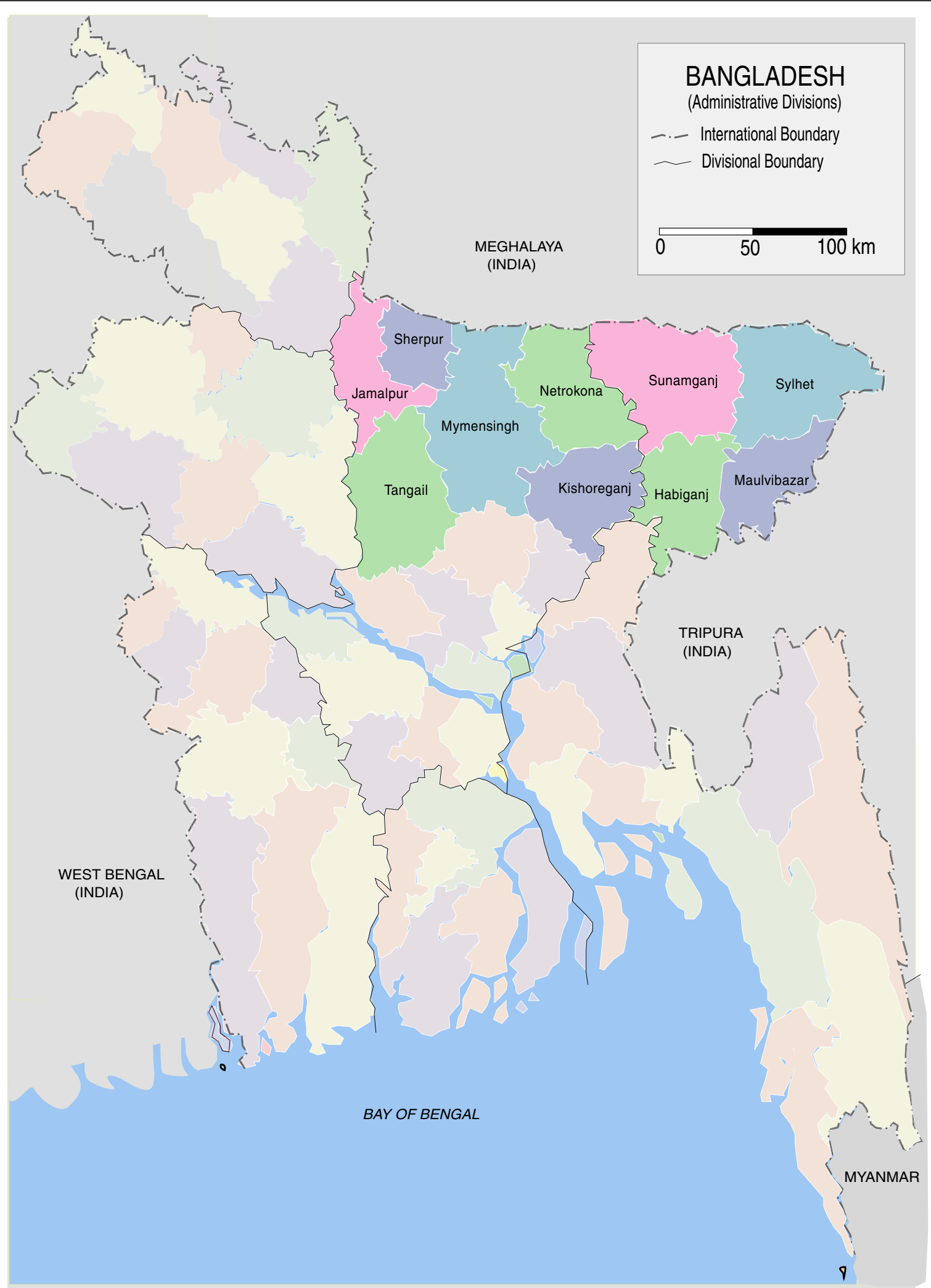

Fig. 1 The map of Bangladesh showing the areas of sample collection (shaded and labelled). (Map template source: https://commons.wikimedia.org/wiki/File:BD_Map_admin.svg) 
Table 1 Oligonucleotide primers and probes used in RT-PCR

\begin{tabular}{|c|c|c|c|c|}
\hline Target Gene & Primer/Probe Name & Sequence & Product size(bp) & Reference \\
\hline \multirow{3}{*}{$\begin{array}{l}\text { M gene (Type A AIV) (TaqMan } \\
\text { Real time RT-PCR) }\end{array}$} & $M+25 P F$ & 5'-AGA TGA GTC TTC TAA CCG AGG TCG-3' & \multirow[t]{3}{*}{$100 \mathrm{bp}$} & \multirow[t]{3}{*}{ [20] } \\
\hline & $M-124 R$ & 5'-TGC AAA AAC ATC TTC AAG TCT CTG-3' & & \\
\hline & $M+64$ Probe & [FAM] 5'-TCA GGC CCC CTC AAA GCC GA-3' [BHQ1] & & \\
\hline \multirow[t]{2}{*}{ HA gene (H5 AIV) } & H5-155 F & 5'-ACA CAT GCY CAR GAC ATA CT-3' & \multirow[t]{2}{*}{$545 \mathrm{bp}$} & \multirow[t]{2}{*}{ [21] } \\
\hline & H5-699R & 5'-CTY TGR TTY AGT GTT GAT GT-3' & & \\
\hline \multirow{2}{*}{$\begin{array}{l}\text { HA gene, full-length (All } \\
\text { Type A AIV) }\end{array}$} & $\mathrm{Bm}-\mathrm{HA}-1 \mathrm{~F}$ & 5'-TATTCGTCTCAGGGAGCAAAAGCAGGGG-3' & \multirow[t]{2}{*}{$1778+29 b p$} & \multirow[t]{2}{*}{ [22] } \\
\hline & Bm-NS-890 (HA) F & 5'-ATA TCG TCT CGT ATT AGT AGA AAC AAG GGT GTT TT-3' & & \\
\hline \multirow[t]{2}{*}{ HA gene, partial (All Type A AIV) } & HA-1134F & 5'-GGR ATG RTH GAY GGN TGG TAY GG-3' & \multirow[t]{2}{*}{$640 \mathrm{bp}$} & {$[23]$} \\
\hline & Bm-NS-890 (HA) R & 5'-ATA TCG TCT CGT ATT AGT AGA AAC AAG GGT GTT Tा-3' & & [22] \\
\hline \multirow{2}{*}{$\begin{array}{l}\text { NA gene, full-length } \\
\text { (All Type A AIV) }\end{array}$} & Ba-NA-1F & 5'-TAT TGG TCT CAG GGA GCA AAA GCA GGA GT-3' & \multirow[t]{2}{*}{$1413+29 b p$} & \multirow[t]{2}{*}{ [22] } \\
\hline & Ba-NA-1413R & 5'-ATATGGTCTCGTATTAGTAGAAACAAGGAGTITIT-3' & & \\
\hline
\end{tabular}

following manufacturer's instruction. The primer sequences are given in Table 1.

\section{Attempted propagation of virus in chicken embryos}

Propagation of virus in chicken embryos from $M$ gene positive samples was attempted following the standard procedure of embryo inoculation by the allantoic route [18]. The growth of virus in the allantoic fluid was checked by haemagglutination test and RT-PCR. One more blind passage was performed for negative samples.

\section{Sequencing of $\mathrm{HA}$ and NA gene}

The virus that could be grown in embryos was sent to OIE-FAO Reference Laboratory, Padova, Italy for genetic characterization. If any $M$ gene posititive sample could not be propagated in embryos, then the RNA isolated from the original swab sample was used for direct amplification of full-length or partial HA and NA genes by one step RT-PCR using universal primer set $[21,22]$ and SuperScript $^{\circ}$ III One-Step RT-PCR System with Platinum $^{\circ}$ Taq DNA polymerase (life Technologies, USA). Primer sequences are given in Table 1. Amplified cDNA was cleaned by gel extraction method using Wizard ${ }^{\circ} \mathrm{SV}$ Gel and PCR Clean-Up System (Promega, USA) according to manufacturer's instruction. The purified RT-PCR products were sequenced in a commercial laboratory (1st Base, Malaysia) using PCR primers.

\section{Phylogenetic analysis}

The raw sequence data were first checked for its quality and then edited and assembled using softwares Chromas (http://technelysium.com.au), Lasergene EditSeq and MegAlign (DNASTAR Inc., USA). Edited sequences were subjected to BLAST search in the GenBank to find the sequences closely related to the sequences established in the present study. HA and NA sequences of the same subtype representing different genetic lineages were downloaded from the GenBank and used in phylogenetic analysis. The multiple alignment using Clustal W algorithym and construction of maximum likelihood phylogenetic tree were performed with MEGA 5.1 software (http:// www.megasoftware.net).

\section{Results}

\section{Serosurveillance}

A total of 871 and 662 serum samples out of 909 and 671 samples collected from Mymensingh and Sylhet division, respectively, were tested by ELISA for antibodies to type A influenza viruses. The remaining 47 samples were not suitable for testing due to excessive hemolysis. The results are presented in Table 2. The prevalence of seropositive ducks in Mymensingh division ranged from 41.48 to $86.24 \%$ during different months and the overall prevalence was $60.73 \%$ (Table 2 ). The prevalence of seropositive ducks was higher during January to April as compared to that during May to July. From Sylhet division the samples were obtained during the period from June to August and the prevalence of seropositive ducks was 40.41 to $52.94 \%$, with overall prevalence of $47.73 \%$. The overall seroprevalence in Mymensingh and Sylhet divisions together was $55.12 \%$.

A total of 80 randomly selected ELISA-positive serum samples were tested for antibodies to $\mathrm{H} 5$ influenza virus by HI. Out of 80 selected ELISA-positive samples 32 had $\mathrm{H} 5 \mathrm{HI}$ antibody titre less than 16 , which is usually considered non-specific [18], and 48 had HI antibody titre between 16 and 512 (Fig. 2). Considering $\mathrm{HI}$ titre $>32$ as H5-specific antibody titre, only 14 out of 80 (17.5\%) ELISA positive samples were $\mathrm{H} 5$ positive.

\section{Virological surveillance and molecular characterization of the virus}

For virological surveillance all the 909 pairs of oropharyngeal and cloacal swabs from ducks of Mymensingh division and 302 pairs (out of 671 pairs) of oropharyngeal 
Table 2 Seroprevalence of type A influenza virus in ducks of Mymensingh and Sylhet divisions during January to July 2013

\begin{tabular}{llll}
\hline Month & $\begin{array}{l}\text { No. of samples } \\
\text { tested }\end{array}$ & $\begin{array}{l}\text { No. of samples } \\
\text { positive }\end{array}$ & $\begin{array}{l}\text { \% of sample } \\
\text { positive }\end{array}$ \\
\hline $\begin{array}{l}\text { Mymensingh division } \\
\text { January 2013 }\end{array}$ & 78 & 61 & $78.20 \%$ \\
February 2013 & 174 & 105 & $60.34 \%$ \\
March 2013 & 134 & 111 & $82.83 \%$ \\
April 2013 & 109 & 94 & $86.23 \%$ \\
May 2013 & 112 & 60 & $53.57 \%$ \\
June 2013 & 170 & 59 & $34.70 \%$ \\
July 2013 & 94 & 39 & $41.48 \%$ \\
Total & 871 & 529 & $60.73 \%$ \\
Sylhet division & & & $40.41 \%$ \\
June 2013 & 146 & 59 & $44.00 \%$ \\
July 2013 & 125 & 50 & $52.94 \%$ \\
August 2013 & 391 & 207 & $47.73 \%$ \\
Total & 662 & 316 & $55.12 \%$ \\
Overall & 1533 & 845 &
\end{tabular}

and cloacal swabs from ducks of Sylhet division were tested for $\mathrm{M}$ gene of type A influenza virus by rRT-PCR. The remaing 369 pairs of samples from Sylhet division could not be tested due to shortage of reagents. Only six samples $(0.5 \%)$ including one oropharyngeal swab and 5 cloacal swabs were positive for type A influenza virus; all the positive samples were from Mymensingh division. However, all the $6 \mathrm{M}$ gene positive samples were negative for $\mathrm{H} 5$ gene on RT-PCR.

Out of $6 \mathrm{M}$ gene positive samples, only one (22-C) could be successfully propagated in chicken embryos.
This sample was charactecterized as H7N5 virus at OIEFAO Reference Laboratory for Avian Influenza, Padova, Italy. The laboratory has made the HA gene sequence of this isolate publicly available in the GenBank (accession no. KM267817). Examination of the deduced amino acid sequence reveals that this H7N5 virus is a low pathogenic one with cleavage site sequence PELPKGR*GLF. The HA gene sequence of this isolate was downloaded from the GenBank and included in phylogenetic analysis in the present study.

For the remaining 5 samples, which were positive for $\mathrm{M}$ gene in rRT-PCR but could not be propagated in embryos, molecular characterization was attempted from the RNA extracted from the original swab samples. We were successful in amplifying nearly fulllength NA gene $(1413+\mathrm{bp})$ and partial HA gene (640 bp) from two samples (18-C and 33-O) by RTPCR (Fig. 3). Nucleotide sequence of the amplified RT-PCR products were established and submitted to GenBank (Accession No. KX185879, KX185880, KX185881, KX185882). Amplification of full-length $\mathrm{HA}$ gene was not successful. The amplified $640 \mathrm{bp}$ fragment of the HA gene was from the $3^{\prime}$ end and that did not cover the cleavage site. BLAST search for homology in the GenBank revealed that the virus from the sample 18$\mathrm{C}$ and 33-O belonged to H1N5 and H2N5 subtype of avian influenza virus, respectively. The summary results of molecular characterization of the viruses are presented in Table 3.

\section{Phylogenetic analysis}

The partial $\mathrm{H} 1$ gene sequence of the sample 18-C [A/duck/ Bangladesh/18-C/2013(H1N5)], H2 gene sequence of the sample 33-O [A/duck/Bangladesh/33-O/2013(H2N5)]

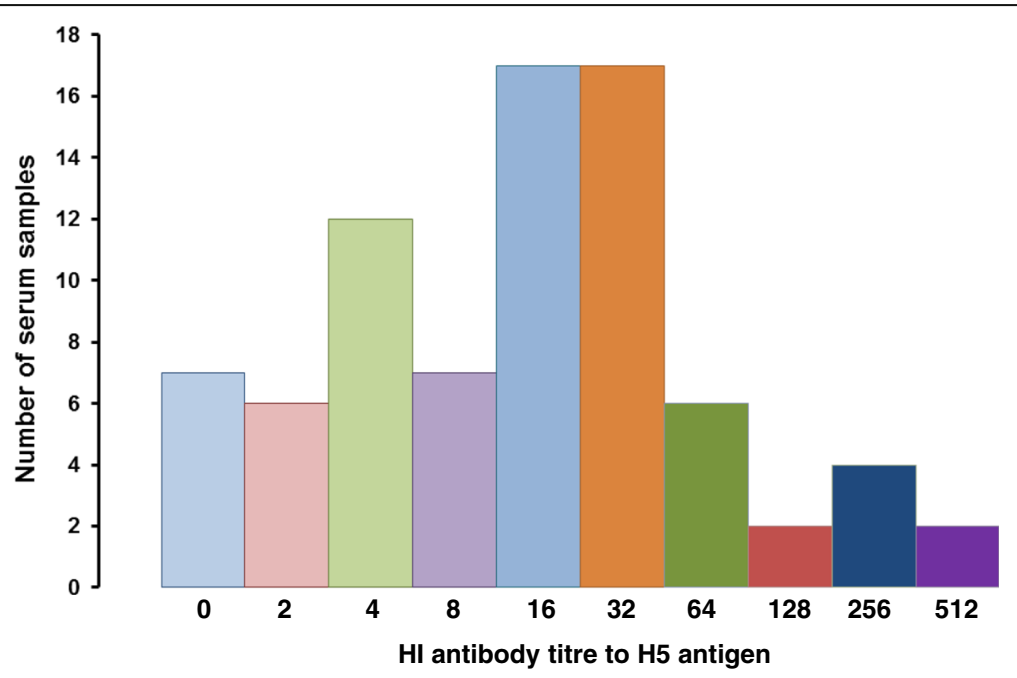

Fig. $2 \mathrm{HI}$ antibody titre against $\mathrm{H} 5$ antigen among Type A avian influenza ELISA-positive serum samples from domestic ducks 


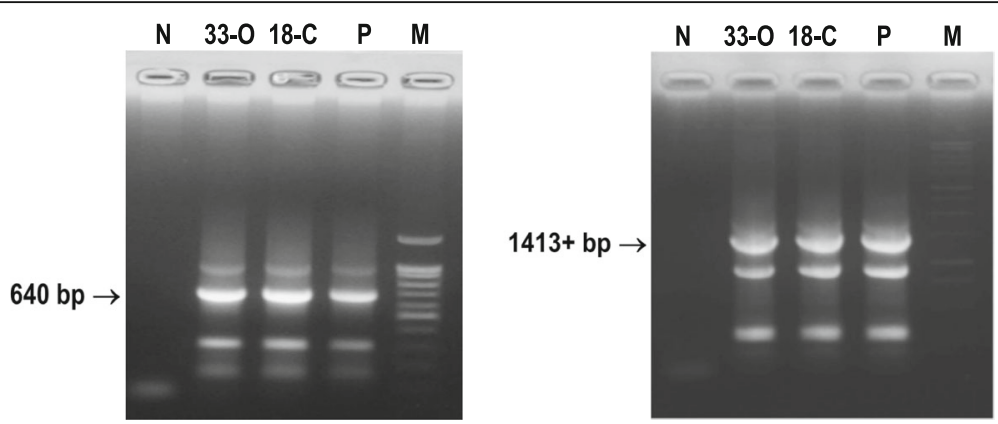

Fig. 3 Amplification of HA (left) and NA (right) gene of avian influenza virus by RT-PCR for sequencing. ( $M=$ marker, $P=$ positive control, $N=$ water control, 330 and $18 \mathrm{C}$ are two samples)

and $\mathrm{H} 7$ gene sequence of the sample $22-\mathrm{C}[(\mathrm{A} /$ duck/ Bangladesh/14VIR1121-1/2013(H7N5)], as well as N5 sequences of the sample $18-\mathrm{C}$ and $33-\mathrm{O}$ were subjected to phylogenetic analysis along with downloaded sequences representing different genetic lineages. The phylogenetic tree revealed that the HA gene segments of 18-C (H1N5), 33-O (H2N5) and 22-C or 14VIR1121-1 (H7N5) virus belonged to Eurasian Avian H1 lineage, Eurasian Avian H2 lineage and Eurasian H7 lineage, respectively (Figs. 4, 5 and 6). The $\mathrm{H} 7$ sequence of the present strain was different from that of influenza $\mathrm{A}(\mathrm{H} 7 \mathrm{~N} 9)$ virus, which caused human infection in China. The NA gene segment of $18-\mathrm{C}$ and 33-O viruses are quite similar and belonged to Eurasian N5 lineage (Fig. 7).

\section{Discussion}

Wild aquatic birds are the natural reservoir of all influenza A viruses [3]. Domestic ducks also have been shown to harbour many subtypes of avian influenza viruses and allow their reassortments [23]. The present study revealed a widespread seroconversion of domestic ducks to Type A influenza virus with an overall

Table 3 Molecular characterization of avian influenza viruses detected from apparently healthy domestic ducks of Mymensingh division in 2013

\begin{tabular}{lllll}
\hline $\begin{array}{l}\text { Sample } \\
\text { ID }\end{array}$ & Sample type & $\begin{array}{l}\text { C value in } \\
\text { rRT-PCR for } \\
\text { Type A influenza } \\
\text { virus M gene }\end{array}$ & $\begin{array}{l}\text { Propagation } \\
\text { in chicken } \\
\text { embryos }\end{array}$ & $\begin{array}{l}\text { Subtyping } \\
\text { result }\end{array}$ \\
\hline $18-\mathrm{C}$ & Cloacal swab & 26 & a $^{\text {a }}$ & H1N5 \\
122-C & Cloacal swab & 35 & - & - \\
22-C & Cloacal swab & 35 & Yes & H7N5 \\
23-C & Cloacal swab & 35 & - & - \\
25-C & Cloacal swab & 35 & - & - \\
$33-0$ & $\begin{array}{l}\text { Oropharyngeal } \\
\text { swab }\end{array}$ & 34 & - & H2N5 \\
& & & & \\
\hline
\end{tabular}

${ }^{\mathrm{a} N o t}$ successful seroprevalence of $60.73 \%$ in Mymensingh and $47.73 \%$ in Sylhet division in 2013. Another study reported 39.76\% seroprevalence of type A avian influenza virus in semiscavenging ducks of Sylhet Hakaluki Haor and Jahangirnagar University Lake areas during winter months of 2009 to 2012 [24]. On further investigation of selected serum samples by $\mathrm{HI}$ test for $\mathrm{H} 5$ antibodies only $17.5 \%$ of ELISA-positive samples were positive for $\mathrm{H} 5$ antibodies using $\mathrm{HI}$ titre $>32$ as the cut-off titre for H5specific antibodies. In West Bengal of India 2.2\% ducks were found to be seropositive in $\mathrm{HI}$ test for $\mathrm{H} 5$ AI considering $>40$ as the cut-off titre [25].

On virological surveillance only one oropharyngeal swab and five cloacal swabs out of 909 sampled ducks from Mymensingh division were found positive for type A influenza virus $M$ gene by rRT-PCR. No positive sample was found from Sylhet division. This prevalence rate of type A influenza virus in domestic ducks is quite low $(0.50 \%)$ as compared to that reported by others in domestic ducks of Bangladesh, such as 5.9\% [26], 22.05\% [24] and 16 out of 39 (41.03\%) [27]. This variation might be due to the different time period of sampling. In the present study the samples were collected during January to August, 2013, where as in the previous studies the samples were collected during the period from 2007 to 2012.

All of the $6 \mathrm{M}$ gene positive samples of the present study were negative for $\mathrm{H} 5$. Attempted propagation of these $M$ gene positive samples in embryos was not successful with the exception of one sample (22-C). This failure to isolate the virus could be due to very low concentration of virus in the samples. The only embryopropagated sample 22-C was characterized as low pathogenic H7N5 at OIE-FAO Reference Laboratory, Padova, Italy. Among the remaining $5 \mathrm{M}$ gene-positive but culture-negative swab samples, it was possible to amplify a $640 \mathrm{bp}$ fragment of HA gene and nearly full-length (1413+ bp) NA gene from two samples (18-C and 33-O). The sample $18-\mathrm{C}$ was characterized as subtype H1N5 


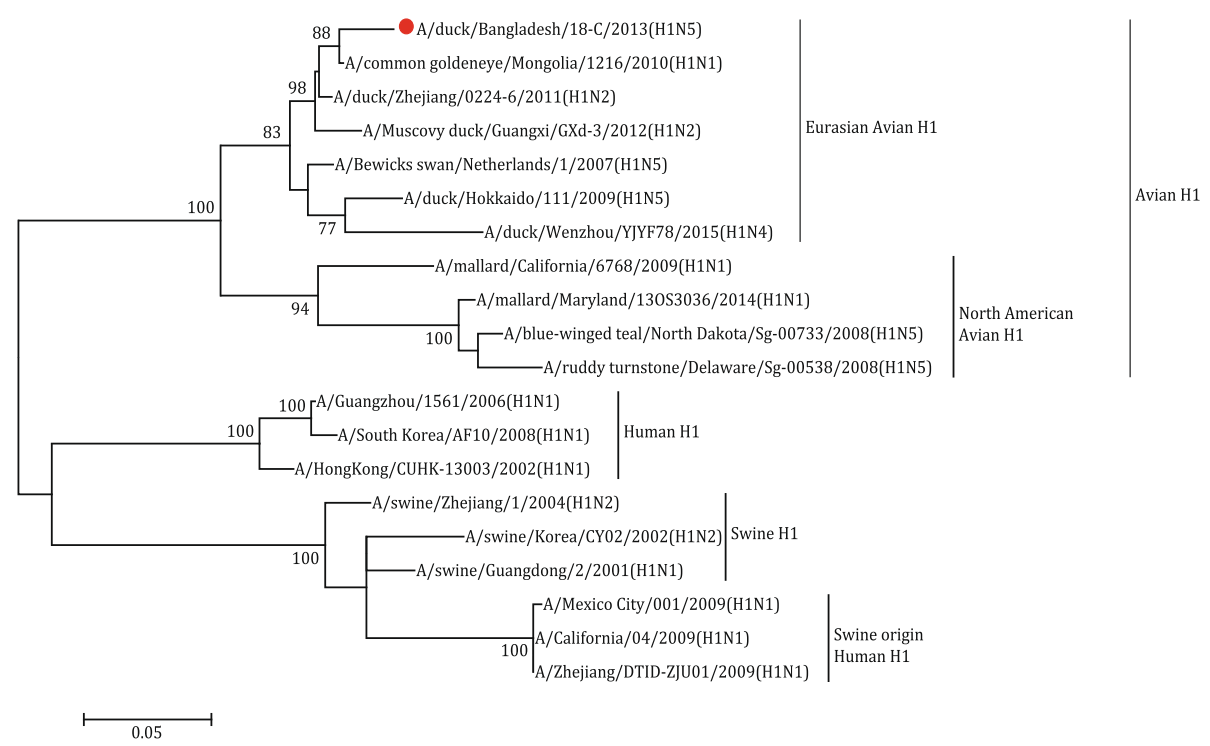

Fig. 4 The Maximum Likelihood (ML) phylogenetic tree based on the partial H1 gene sequences (600 bp) of H1N5 virus of the present study and representative $\mathrm{H} 1$ viruses of different genetic lineages. The scale indicates the number of substitutions per site. The H1N5 sequence of the present study is indicated with a closed circle symbol

and the sample 33-O as subtype H2N5. Aquatic birds are known to harbour a wide variety of avian influenza viruses. So the detection of viruses of three different subtypes (H7N5, H1N5 and H2N5) is not surprising. In an earlier study 14 different subtypes of LPAI viruses including H1N1, H1N3, H2N4, H3N2, H3N6, H3N8, H4N2, H4N6, H5N2, H6N1, H6N7, H7N9, H9N2 and H11N3 were identified from domestic ducks of Bangladesh [27]. Isolation of $\mathrm{H} 1 \mathrm{~N} 1, \mathrm{H} 1 \mathrm{~N} 2$ and $\mathrm{H} 1 \mathrm{~N} 3$ viruses have been reported from wild and domestic ducks in Korea [28],
H1N3 and H1N9 viruses from free-range ducks in Thailand [29] and H2N7 and H2N2 virus from domestic ducks in China [30,31]. It was interesting that the $\mathrm{N}$ gene component of all of the three viruses (H1N5, H2N5 and H7N5) detected in the present study was N5. However, in the previous study [27] all the different N subtypes except N5 were detected in domestic ducks of Bangladesh. Taken together, the findings of these two studies reveal that all the $9 \mathrm{~N}$ genes are present in domestic ducks of Bangladesh. Phylogenetically the HA gene of H1N5, H2N5 and H7N5 viruses
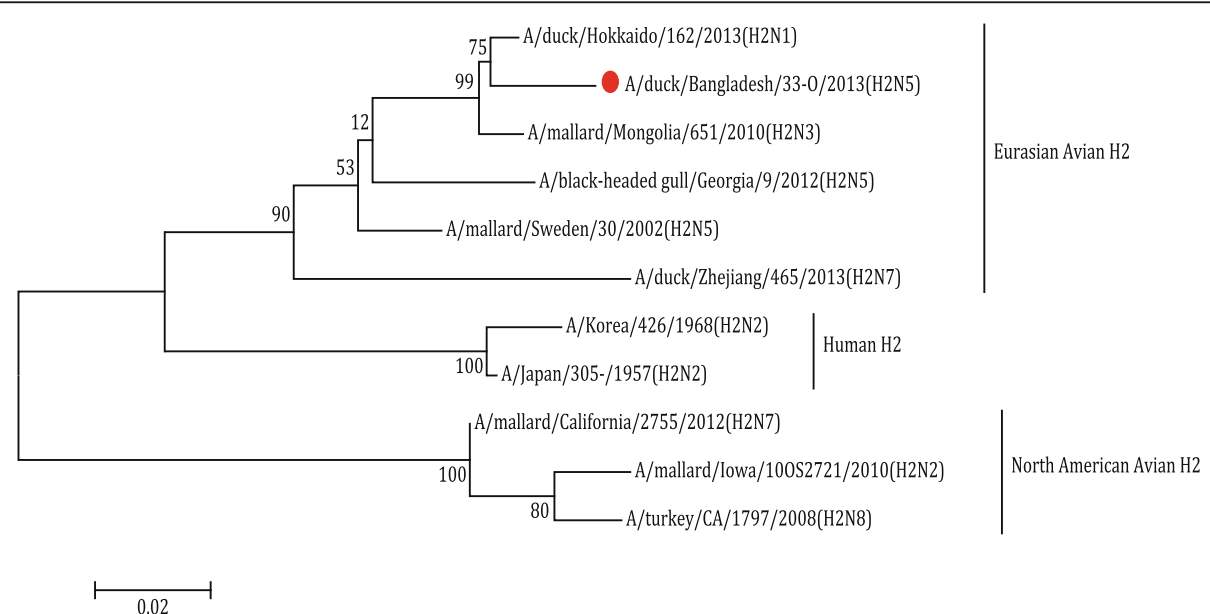

Fig. 5 The Maximum Likelihood (ML) phylogenetic tree based on the partial H2 gene sequences (600 bp) of H2N5 virus of the present study and representative $\mathrm{H} 2$ viruses of different genetic lineages. The scale indicates the number of substitutions per site. The H2N5 sequence of the present study is indicated with a closed circle symbol 


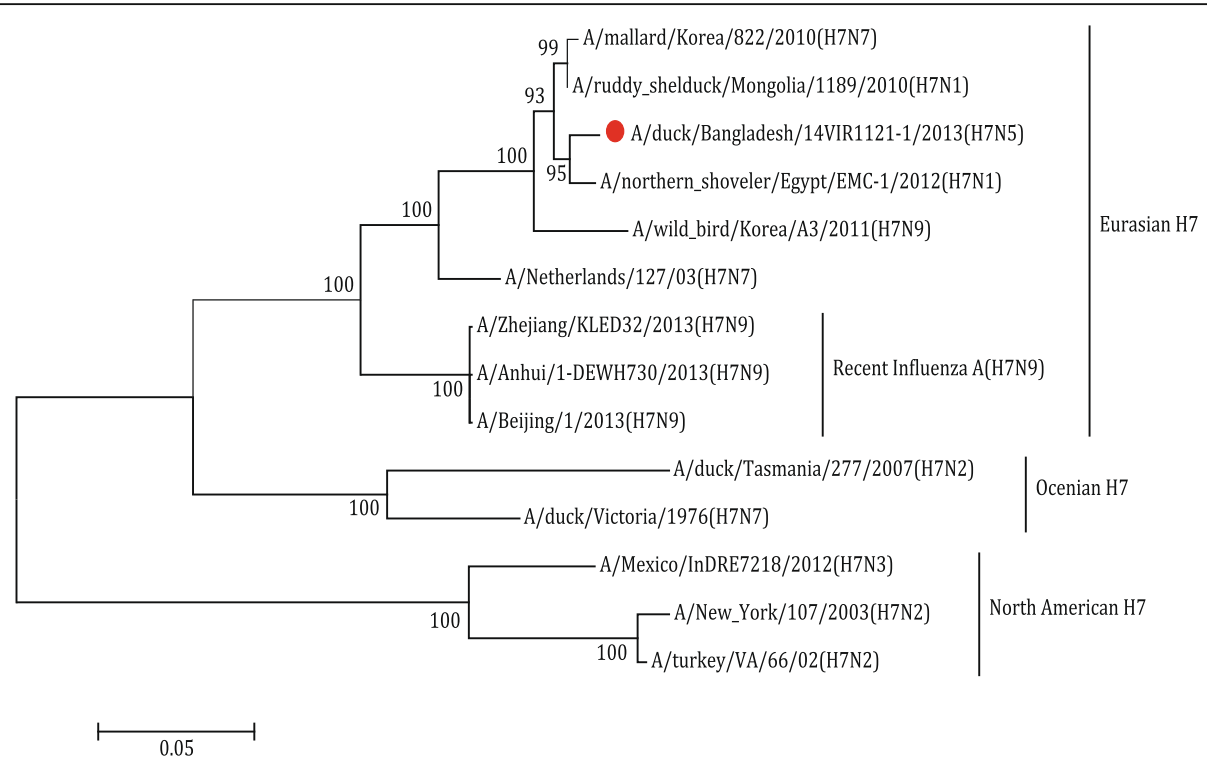

Fig. 6 The Maximum Likelihood (ML) phylogenetic tree based on the H7 gene sequences of H7N5 virus of the present study and representative $\mathrm{H} 7$ viruses of different genetic lineages. The scale indicates the number of substitutions per site. The H7N5 sequence of the present study is indicated with a closed circle symbol

belonged to Eurasian avian lineages as observed in the previous study [27]. The HA gene of H7N5 was distinct from the HA gene of the newly emerged Influenza A(H7N9) virus. The N5 gene of H1N5 and H2N5 viruses were very similar and also belonged to Eurasian lineage; the NA gene sequence of H7N5 virus was not available.

\section{Conclusions}

Present study shows that $55.12 \%$ of the ducks were seropositive for antibodies to Type A influenza virus and a small proportion of Type A influenza virus positive ducks (14 out of 80 randomly selected samples) had previous exposure to $\mathrm{H} 5$ subtype viruses, probably $\mathrm{H} 5 \mathrm{~N} 1$ HPAI or H5N2 LPAI viruses. Active shedding of AI virus at the time of the study was very limited $(0.5 \%)$. Three viruses were characterized as H1N5, H2N5 and H7N5 subtypes and no H5N1 virus was detected. Findings of the present study warrant further detailed surveillance on avain influenza virus in ducks for better understanding of the ecology of avian influenza viruses in domestic duck population.

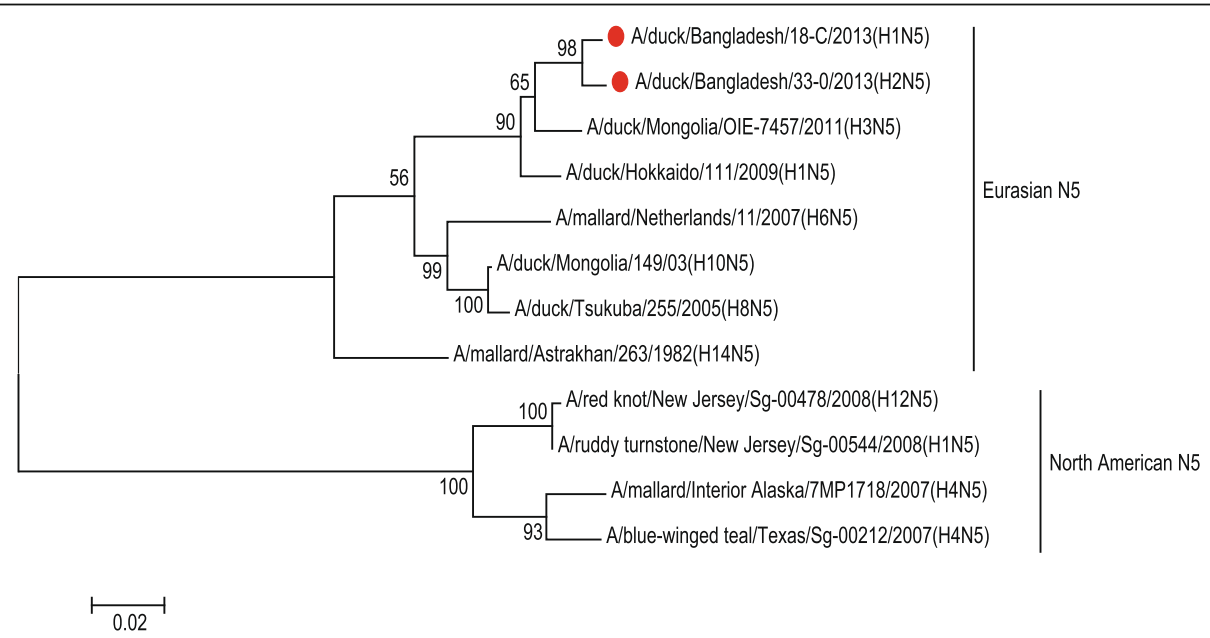

Fig. 7 The Maximum Likelihood (ML) phylogenetic tree based on the N5 gene sequences of H1N5 and H2N5 viruses of the present study and representative N5 viruses of different genetic lineages. The scale indicates the number of substitutions per site. The H1N5 and H2N5 sequences of the present study are indicated with closed circle symbols 


\section{Abbreviations}

Al: Avian influenza; ELISA: Enzyme-linked immunosorbent assay; FAO: Food and Agriculture Organization; HA: Haemagglutinin; HI: Haemagglutination inhibition; HPAl: Highly pathogenic; LPAI: Low pathogenic avian influenza; NA: Neuraminidase; OIE: Office international des epizooties; rRT-PCR: Real time Reverse transcription- polymerase chain reaction; RT-PCR: Reverse transcription- polymerase chain reaction; S/N: Sample - negative; WOAH: World Organization for Animal Health

\section{Funding}

The study was supported by FAO, Bangladesh.

\section{Availability of data and materials}

The sequence dataset supporting the conclusions of this article is available in the GenBank (http://www.ncbi.nlm.nih.gov/genbank/). The accession numbers are mentioned in the text.

\section{Authors' contributions}

RDS and MG contributed to acquisition of data, analysis and interpretation of data; RDS drafted the manuscripts; EHC and MRI conceived and designed the study, supervised the research work and approved the manuscript.

\section{Competing interests}

The authors declare that they have no competing interests.

\section{Consent for publication}

Not applicable.

\section{Ethics approval}

Swab and serum samples were collected from ducks by the qualified veterinarians of the Department of Livestock Services following standard procedures approved by the Animal Ethics Committee of the Faculty of Veterinary Science of Bangladesh Agricultural University, Mymensingh, Bangladesh.

\section{Publisher's Note}

Springer Nature remains neutral with regard to jurisdictional claims in published maps and institutional affiliations.

\section{Author details}

'Department of Pathology, Bangladesh Agricultural University, Mymensingh, Bangladesh. ${ }^{2}$ National Reference Laboratory for Avian Influenza, Bangladesh Livestock Research Institute, Savar, Dhaka, Bangladesh.

Received: 15 September 2016 Accepted: 9 June 2017

Published online: 17 June 2017

\section{References}

1. Fouchier RA, Munster V, Wallensten A, Bestebroer TM, Herfst S, Smith D, et al. Characterization of a novel influenza a virus hemagglutinin subtype (H16) obtained from black-headed gulls. J Virol. 2005;79:2814-22.

2. Tong S, Zhu X, Li Y, Shi M, Zhang J, Bourgeois M, et al. New world bats harbor diverse influenza a viruses. Plos Pathog. 2013:9:e1003657.

3. Krauss S, Obert CA, Franks J, Walker D, Jones K, Seiler P, et al. Influenza in migratory birds and evidence of limited intercontinental virus exchange. Plos Pathog. 2007:3:e167

4. Sonnberg S, Webby RJ, Webster RG. Natural history of highly pathogenic avian influenza H5N1. Virus Res. 2013;178:63-77.

5. Islam MR, Baqi MA, Giasuddin M, Samad MA. Molecular characterization and phylogenetic analysis of highly pathogenic H5N1 avian influenza virus of chickens of Bangladesh. Proceedings of the Bangkok International Conference on Avian Influenza 2008: Integration from Knowledge to Control. Bangkok: 2008

6. Biswas PK, Christensen JP, Ahmed SSU, Barua H, Das A, Rahman MH, et al Avian influenza outbreaks in chickens, Bangladesh. Emerg Infect Dis. 2008, 14:1909-12.

7. OIE: World Animal Health Information Database (WAHID) Interface. Disease information. Available at http://www.oie.int/wahis_2/public/wahid.php/ Diseaseinformation/Immsummary. Accessed 8 Sept 2016.
8. Islam MR, Haque ME, Giasuddin M, Chowdhury EH, Samad MA, Parvin R, et al. New introduction of clade 2.3.2.1 avian influenza virus (H5N1) into Bangladesh. Transbound Emerg Dis. 2012;59:460-3.

9. Khan SU, Berman L, Haider N, Gerloff N, Rahman MZ, Shu B, et al. Investigating a crow die-off in January-February 2011 during the introduction of a new clade of highly pathogenic avian influenza virus H5N1 into Bangladesh. Arch Virol. 2014;159:509-18.

10. Haider N, Sturm-Ramirez K, Khan SU, Rahman MZ, Sarkar S, Poh MK, Shivaprasad HL, Kalam MA, Paul SK, Karmakar PC, Balish A,Chakraborty A, Mamun AA, Mikolon AB, Davis CT, Rahman M, Donis RO, Heffelfinger JD, Luby SP, Zeidner N. Unusually High Mortality in Waterfowl Caused by Highly Pathogenic Avian Influenza A (H5N1) in Bangladesh. Transboun Emerg Dis. 2015. doi:10.1111/tbed.12354. Epub ahead of print.

11. Marinova-Petkova A, Feeroz MM, Rabiul Alam SM, Kamrul Hasan M, Akhtar S, Jones-Engel $\mathrm{L}$, et al. Multiple introductions of highly pathogenic avian influenza H5N1 viruses into Bangladesh. Emerg Microbe Infect. 2014;3:e11. doi:10.1038/emi.

12. Haque ME, Giasuddin M, Chowdhury EH, Islam MR. Molecular evolution of H5N1 highly pathogenic avian influenza viruses in Bangladesh between 2007 and 2012. Avian Pathol. 2014;43:183-94.

13. WHO. Cumulative number of confirmed human cases for avian influenza A(H5N1) reported to WHO, 2003-2015. Available at http://www.who.int/ influenza/human_animal_interface/2016_01_20_tableH5N1.pdf?ua=1. Accessed 8 Sept 2016

14. Negovetich NJ, Feeroz MM, Jones-Engel L, Walker D, Alam SMR, Hasan K, et al. Live bird markets of Bangladesh: H9N2 viruses and the near absence of highly pathogenic H5N1 influenza. Plos One. 6:e19311. doi:10.1371/ journal.pone.0019311.

15. Jannat N, Chowdhury EH, Parvin R, Begum JA, Giasuddin M, MAHNA K, et al Investigation of an outbreak of low pathogenic avian influenza in poultry in Bangladesh. Intl J Livestock Res. 2013;3:21-32.

16. Parvin R, Heenemann K, Halami MY, Chowdhury EH, Islam MR, Vahlenkamp TW. Full-genome analysis of avian influenza virus H9N2 from Bangladesh reveals internal gene reassortments with two distinct highly pathogenic avian influenza viruses. Arch Virol. 2014;159:1651-61.

17. FAOSTAT: Live animals_Bangladesh_Stock_Ducks_2014. Available at http:// fenix.fao.org/faostat/beta/en/\#data/QA. Accessed 8 Sept 2016.

18. OIE: Manual of Diagnostic Tests and Vaccines for Terrestrial Animals 2016. Chapter 2.3.4. Avian influenza (infection with avian influenza viruses). Available at http://www.oie.int/fileadmin/Home/eng/Health_standards/ tahm/2.03.04_Al.pdf. Accessed 8 Sept 2016.

19. Spackman E, Senne DA, Myers TJ, Bulaga LL, Garber LP, Perdue ML, et al Development of a real-time reverse transcriptase PCR assay for type a influenza virus and the avian $\mathrm{H} 5$ and $\mathrm{H} 7$ Hemagglutinin subtypes. J Clin Microbiol. 2002:40:3256-60

20. Lee MS, Chang PC, Shien JH, Cheng MC, Shieh HK. Identification and subtyping of avian influenza viruses by reverse transcription-PCR. J Virol Methods. 2001;97:13-22.

21. Hoffmann E, Stech J, Guan Y, Webster RG, Perez DR. Universal primer set for the full-length amplification of all influenza a viruses. Arch Virol. 2001;146: 2275-89.

22. Lindsay LL, Kelly TR, Plancarte M, Schobel S, Lin X, Dugan VG, et al. Avian influenza: mixed infections and missing viruses. Viruses. 2013:5:1964-77.

23. Deng G, Tan D, Shi J, Cui P, Jiang Y, Liu L, et al. Complex reassortment of multiple subtypes of avian influenza viruses in domestic ducks at the Dongting Lake region of China. J Virol. 2013;87:9452-62.

24. Khatun A, Giasuddin M, Islam KM, Hanom S, Samad MA, Islam MR, et al. Surveillance of avian influenza virus type a in semi-scavenging ducks in Bangladesh. BMC Vet Res. 2013;9:196.

25. Pawar SD, Kale SD, Rawankar AS, Koratkar SS, Raut CG, Pande SA, et al. Avian influenza surveillance reveals presence of low pathogenic avian influenza viruses in poultry during 2009-2011 in the West Bengal state, India. Virol J. 2012;9:151.

26. Annon. Avian influenza virus surveillance at live bird markets in Bangladesh, 2007-2012. ICDDR,B Health Sci Bull. 2012;11:8-16.

27. Gerloff NA, Khan SU, Zanders N, Balish A, Haider N, Islam A, et al. Genetically diverse low pathogenicity avian influenza a virus subtypes co-circulate among poultry in Bangladesh. Plos One. 2016;11:e0152131.

28. Jeong OM, Kim YJ, Choi JG, Kang HM, Kim MC, Kwon JH, et al. Genetic characterization of $\mathrm{H} 1$ avian influenza viruses isolated from migratory birds and domestic ducks in Korea. Virus Genes. 2011;42:55-63. 
29. Chaiyawong S, Boonyapisitsopa S, Jairak W, Nonthabenjawan N, Tangwangvivat R, Bunpapong N, et al. Genetic characterization of influenza a virus subtypes H1N3 and H1N9 isolated from free-grazing ducks in Thailand. Arch Virol. 2016;161:2819-24.

30. Peng $X$, Wu H, Jin C, Yao H, Lu X, Cheng L, et al. Sequence and phylogenetic analysis of H2N7 avian influenza viruses isolated from domestic ducks in Zhejiang Province, eastern China, 2013. Virus Genes. 2014:48:391-6.

31. Ma MJ, Yang XX, Qian YH, Zhao SY, Hua S, Wang TC, et al. Characterization of a novel reassortant influenza a virus (H2N2) from a domestic duck in eastern China. Sci Rep. 2014;4:7588.

Submit your next manuscript to BioMed Central and we will help you at every step:

- We accept pre-submission inquiries

- Our selector tool helps you to find the most relevant journal

- We provide round the clock customer support

- Convenient online submission

- Thorough peer review

- Inclusion in PubMed and all major indexing services

- Maximum visibility for your research

Submit your manuscript at www.biomedcentral.com/submit
Biomed Central 